\title{
The Isolation of Tyrosinase from Aspergillus nidulans, Its Kinetic and Molecular Properties and Some Consideration of Its !Activity in vivo
}

\author{
By A. T. BULL \\ Biological Laboratory, University of Kent, Canterbury \\ AND B. L. A. CARTER \\ Rosenstiel Basic Medical Science Research Center, Brandeis University, \\ Waltham, Massachusetts, 02154, U.S.A. \\ (Received I9 June I972; revised I I September 1972)

\begin{abstract}
SUMMAR Y
A single-step procedure was developed which enabled the phenol oxidase of Aspergillus nidulans to be recovered in a state of high purity. Ion-exchange chromatography was used to separate the phenol oxidase from an inhibitory protein. Kinetic analysis of the enzyme revealed that it was a tyrosinase (EC. I . I0.3. I) and had a variable ratio of $o$-hydroxylase to $o$-diphenol oxidase activity. The enzyme had a relatively low affinity for oxygen $\left(K_{m}\right.$ of $\left.\mathrm{I} 25 \mu \mathrm{M}\right)$ but, compared to other phenol oxidases, a high affinity for its phenolic substrate $\left(K_{m}\right.$ DOPA of $250 \mu \mathrm{M})$. The Aspergillus tyrosinase was heterogeneous and appeared to exist in a monomer (mol. wt $\left.\mathrm{I} \cdot 3 \times 10^{5}\right)$-tetramer $\left(5 \cdot 2 \times \mathrm{IO}^{5}\right)$ equilibrium. The protein inhibitor was of similar size to the tyrosinase monomer and caused non-competitive inhibition of the enzyme. Both of the tyrosinase activities and the inhibitor had a substantial component of ribonucleic acid. The RNA was not removed from the enzymes or the inhibitor during purification; non-specific complexes may be formed between these proteins and RNA or true ribonucleoproteins may exist. A model is proposed for the physiological function of tyrosinase in A. nidulans under conditions where secondary metabolism does not occur.
\end{abstract}

\section{INTRODUCTION}

Secondary metabolism in the mould Aspergillus nidulans leads to a massive synthesis (up to $28 \%, \mathrm{w} / \mathrm{w}$ ) of melanin, which is mediated by the action of a phenol oxidase. In previous publications we have discussed the physicochemical nature of this pigment (Bull, I970) and reported on the kinetics of phenol oxidase production in batch and chemostat cultures (Carter \& Bull, 1969). After considerable difficulty in isolating this enzyme, a large mol. wt inhibitor was detected in mycelial extracts and a procedure was developed to separate the enzyme from this endogenous inhibitor.

This paper deals with the problems of isolating and purifying the phenol oxidase of Aspergillus nidulans and with its kinetic and molecular characterization as a tyrosinase. Roles for phenol oxidases in the primary metabolism of fungi and plants frequently have been proposed although substantiating evidence has been difficult to obtain. A model is proposed for phenol oxidase function in the primary metabolism of Aspergillus in addition to its involvement in melanogenesis and secondary metabolism. 


\section{METHODS}

Microbiological procedures. Most of the results reported in this paper were obtained from experiments with strain BWB224 (Glasgow) of Aspergillus nidulans. Occasionally studies were made of mutant strains (Bull \& Faulkner, 1964, 1965) in which melanogenesis was blocked to varying extents.

Cultures were made in a $\mathrm{I} .51$ fermenter having a working volume of $\mathrm{I} \cdot 21$ and in which the conditions of aeration and agitation were as described by Carter \& Bull (I969). A strongly buffered glucose-nitrate-salts medium, pH 6.6 (Carter \& Bull, I969), was used for the culture of all strains.

Enzyme extraction and purification. The mycelium was collected by filtration, and crude extracts prepared by grinding it with acid-washed sand in $0^{\circ} \mathrm{I}$ M-phosphate buffer, $\mathrm{pH} 7$, containing Triton X-I00 (I \%) (Carter, Bull, Pirt \& Rowley, I97I).

After numerous attempts to obtain preparations with reproducible phenol oxidase activity the following isolation procedure was established. The extract (about $15 \mathrm{ml}$ ) was applied to a column $(60 \times 2.8 \mathrm{~cm})$ of diethylaminoethyl cellulose (Whatman DE $52 ; \mathrm{H}$. Reeve Angel \& Co. Ltd, London, E.C. 4) previously equilibrated with $5 \mathrm{~mm}$-tris-HCl buffer, $\mathrm{pH} 8 \cdot 3$. Elution was started with the $5 \mathrm{~mm}$-tris-HCl buffer when the sample had soaked into the cellulose and, after $300 \mathrm{ml}$ of buffer had passed through the column, a linear gradient of sodium chloride was incorporated. The enzyme was adsorbed very strongly on to DEAEcellulose and was not eluted until the gradient concentration approached $500 \mathrm{~mm}-\mathrm{NaCl}$. Fractions $(5 \mathrm{ml})$ were collected at $4{ }^{\circ} \mathrm{C}$ at an elution rate of $50 \mathrm{ml} / \mathrm{h}$.

Fractions with phenol oxidase activity were pooled and concentrated either by freezedrying or by treatment with coarse-grade Sephadex G-25 (Pharmacia (GB) Ltd, Uxbridge). Dry Sephadex G-25 was added to the enzyme solution and allowed to swell at $4{ }^{\circ} \mathrm{C}$ for I 5 min. Subsequently the liquid phase was recovered by filtration. In this way a threefold concentration of the enzyme was achieved with a recovery of about $80 \%$. Repeated treatment with Sephadex was used to concentrate the enzyme further.

The concentrated enzyme solution $(5 \mathrm{ml})$ was applied to a column of Sephadex G-200 (Pharmacia (GB) Ltd) $(35 \times \mathrm{I} \cdot 5 \mathrm{~cm})$ previously equilibrated with $5 \mathrm{~mm}$-phosphate buffer, $\mathrm{pH} 7 \cdot 0$, containing I $\mathrm{M}-\mathrm{NaCl}$, also used as the eluting solvent, and fractions $(5 \mathrm{ml})$ were collected at $4{ }^{\circ} \mathrm{C}$. The void volume of the column was measured with a $0 \cdot 1 \%(\mathrm{w} / \mathrm{v})$ solution of Blue Dextran (Pharmacia (GB) Ltd). Two phenol oxidases were resolved by this means and had specific activities of 215 and $183 \mathrm{u} / \mathrm{mg}$ protein respectively.

Enzyme assays and units. Two procedures were used for the routine assay of the phenol oxidase. The first, the chronometric assay, was an indirect spectrophotometric assay based on the method of El-Bayoumi \& Frieden (1957). The indirect oxidation of ascorbic acid was followed at $265 \mathrm{~nm}$ in a Unicam SP $800 \mathrm{~B}$ spectrophotometer. The reaction mixture $(3.0 \mathrm{ml})$ contained 50 mM-phosphate buffer, pH 6.8, I mM-L-ascorbic acid, I mM-DL-3,4-dihydroxyphenyl alanine (DOPA) and O.I mM-EDTA. The cuvette was shaken vigorously to aerate the reaction mixture after addition of the enzyme $(0.2 \mathrm{ml})$. Initial reaction rates were recorded at $30{ }^{\circ} \mathrm{C}$ before product inhibition occurred and while zero order kinetics applied. An international unit of activity $(\mathrm{u})$ measured in this way was defined as that amount of enzyme which catalysed the conversion of I $\mu$ mole of DOPA $/ \mathrm{min}$.

The second assay, a polarographic method, was based on the measurement of oxygenuptake rates in reaction mixtures similar to that detailed above. The oxygen-electrode cell and oxygen analyser have been described previously (Carter \& Bull, I97I). All reaction components $(3.0 \mathrm{ml})$ were added to the cell and allowed to equilibrate at $30^{\circ} \mathrm{C}$. The reaction 
was then started by the injection of DOPA solution $(0.5 \mathrm{ml})$ via the entry port by means of a Hamilton syringe (Hamilton Co., Whittier, California, U.S.A.). A unit of activity (u) measured in this way was defined as that amount of enzyme which catalysed the utilization of $\mathrm{I} \mu \mathrm{mol}$ of $\mathrm{O}_{2} / \mathrm{min}$.

A sample of tyrosinase prepared from common mushroom was purchased from KochLight Co. Ltd, Colnbrook, Buckinghamshire.

Isolation and assay of the endogenous protein inhibitor. The endogenous protein inhibitor of Aspergillus nidulans phenol oxidase was separated from the enzyme by ion exchange chromatography (see Results section) but has not been purified further. A unit of inhibitor activity was defined arbitrarily as that amount which caused $50 \%$ inhibition of a standard enzyme preparation (equivalent to $15 \mathrm{u}$ ).

Disc electrophoresis. Polyacrylamide gels $(7.5 \%$, w/v) were prepared in $43 \mathrm{~mm}$-tris-glycine buffer, pH 8.3, according to the method of Davies (I964); sample and spacer gels were not used. Enzyme samples ( $10 \mu \mathrm{l}$ ) were layered directly on the top of the gel and electrophoresis was done with the tris-glycine buffer in both the anode and cathode reservoirs. A few drops of bromophenol-blue solution were added to the upper reservoir to act as a marker during electrophoresis. Enzyme preparations were analysed by applying a current of 3 to $5 \mathrm{~mA} /$ tube for 20 to $40 \mathrm{~min}$ at $4{ }^{\circ} \mathrm{C}$. Phenol oxidases were located by incubating the gels with $20 \mathrm{~mm}$ DL-DOPA in phosphate buffer, pH 6.8, for $60 \mathrm{~min}$ at $37^{\circ} \mathrm{C}$.

Paper electrophoresis. Electrophoresis was done on Whatman no. I paper which was pretreated occasionally with bovine-serum albumin (a I \% solution in 50 mm-phosphate buffer, $\mathrm{pH} 6 \cdot \mathrm{I}$ ) to facilitate migration of the enzyme. An operating voltage of $100 \mathrm{~V}$ was applied for $\mathrm{I} 8 \mathrm{~h}$ at $4{ }^{\circ} \mathrm{C}$; enzyme was located by spraying the strips with $20 \mathrm{~mm}$-DOPA and incubating them in a humidity chamber at $37^{\circ} \mathrm{C}$. Protein bands were located with bromophenol blue and scanned photometrically (EEL Scanner, Evans Electroselenium Ltd, Halstead, Essex).

Protein was determined by the method of Lowry, Rosebrough, Farr \& Randall (I95I) with bovine-serum albumin as the standard, and RNA was determined by the orcinol method of Schneider (I957) with yeast RNA (B.D.H., Poole, Dorset) as the standard.

\section{RESULTS}

Enzyme preparation. A variety of methods, including ultrasonication, maceration in a blender, passage through a Hughes Press, high-speed shaking with ballotini and grinding with sand, were used to prepare extracts of Aspergillus nidulans. Of these procedures, disruption in the Hughes Press was the most effective in releasing protein $(274 \mathrm{mg} / \mathrm{g}$ dry wt mycelium). However, although grinding the mycelium with sand was much less efficient (52 $\mathrm{mg} / \mathrm{g}$ dry wt mycelium), it did allow large quantities of fungus to be processed easily and quickly, thereby providing sufficient material for subsequent treatment. After hyphal breakage, the coarse debris was removed by low speed centrifugation $\left(2400 \mathrm{~g}, 5 \mathrm{~min}, 4{ }^{\circ} \mathrm{C}\right)$. The phenol oxidase activity of the resulting supernatant was disappointingly low and erratic and frequently activity could not be detected. Consequently an attempt was made to reveal the reason for such poor recovery.

Phenol oxidases from a wide range of organisms are known to be particulate (Pomerantz, I963; Karlson, Mergenhager \& Sekeris, I964; Mayer, Harel \& Ben-Shaul, I966) and the possibility that the Aspergillus enzyme was present in an inactive bound state was examined. The low-speed supernatants obtained above were treated with $\mathrm{I} \%$ solutions of either digitonin, Triton X-I00 or sodium desoxycholate for $45 \mathrm{~min}$ in the cold and then centrifuged 


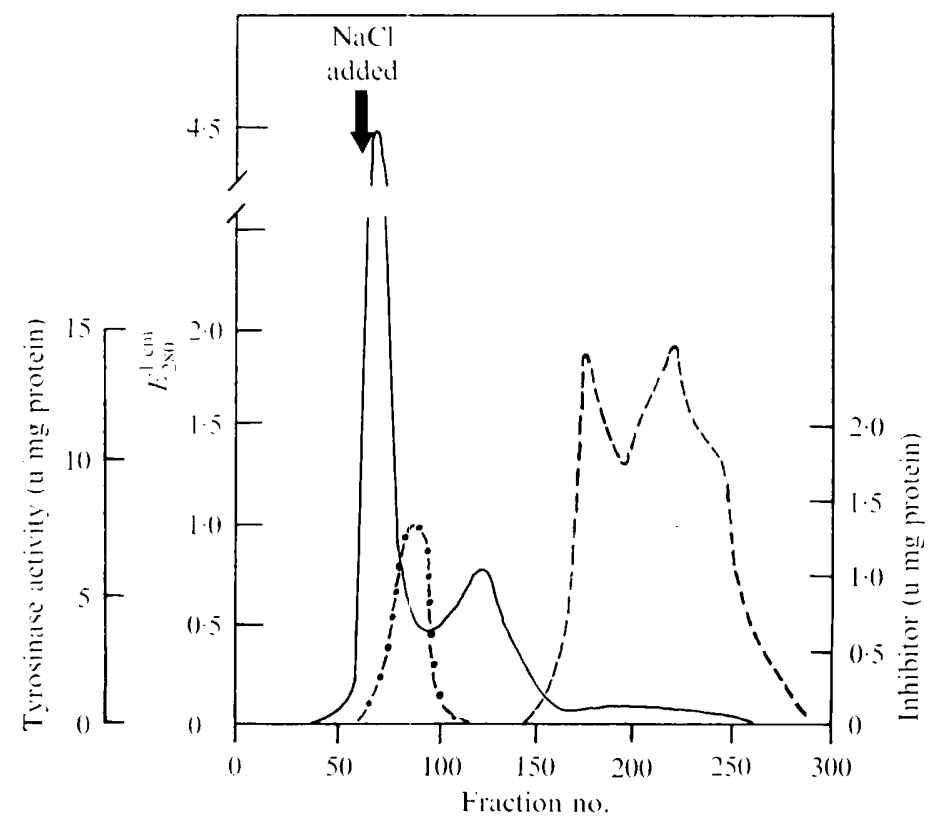

Fig. I. Ion-exchange chromatography of a crude mycelial extract of Aspergillus nidulans. Extract ( $5 \mathrm{ml}$ ) was applied to a column $(60 \times 2.8 \mathrm{~cm})$ of DEAE-cellulose, equilibrated with $5 \mathrm{~mm}$-tris- $\mathrm{HCl}$ buffer, $\mathrm{pH} 8 \cdot 2$, and eluted with this buffer $(50 \mathrm{ml} / \mathrm{h})$. After $300 \mathrm{ml}$ buffer had passed through the column a sodium chloride gradient was incorporated. Protein (-) was estimated from $E_{280}$ and tyrosinase $(---)$ was determined by the chronometric assay. $(-\cdot-\cdot)$, Endogenous inhibitor.

$\left(95000 \mathrm{~g}, 30 \mathrm{~min}, 4^{\circ} \mathrm{C}\right)$. The supernatants were assayed for phenol oxidase. The use of Triton X-I00 and digitonin both produced some activity but the levels remained low and inconsistent. Finally, organic solvents (butan-I-Ol, $5 \%$, v/v; acetone, 30\%, 50\%, 60\% and $70 \%, v / v)$ were used in similar attempts to solubilize the enzyme. No activity resulted from the treatment with butan-I-ol but the $60 \%$ acetone precipitate had low phenol oxidase activity. These experiments with surfactants and acetone suggested that phenol oxidase was being solubilized but that the released enzyme was then masked by some soluble inhibitor(s). Endogenous quinones and polyphenols inhibit the activity of many enzymes. Thus, our failure to detect phenol oxidase activity in extracts of $A$. nidulans might be attributable to this type of inhibition and experiments were designed (i) to prevent the formation of $o$ quinones; (ii) to prevent the interaction of the enzyme with endogenous polyphenols; and (iii) to separate the enzyme from potential phenolic inhibitors.

The addition of $4 \mathrm{~mm}$-L-ascorbate to the extraction medium, while preventing $o$-quinone formation, did not lead to enzyme recovery. Similarly removal of polyphenols with $5 \%$ $(\mathrm{w} / \mathrm{v})$ polyvinylpyrrolidone(PVP, a soluble preparation of mol. wt 25000)(Sanderson, I965) failed to produce activity. In retrospect this latter result was not surprising because the Aspergillus phenol oxidase is severely inhibited by PVP. Finally, extracts were passed through beds of dextran gels in an attempt to remove presumed inhibitors. Chromatography of the extract on Sephadex G-25 gel did not result in enzyme recovery in the eluant, however, when a G-200 gel was used, successful production of activity, albeit slight ( $0.54 \mathrm{u} / \mathrm{mg}$ protein), was obtained reproducibly. The enzyme was eluted immediately after the void volume of eluting buffer had passed through the column, which indicated a mol. wt of the order of 500000 . Ion-exchange chromatography ultimately proved to be the most effective means of 


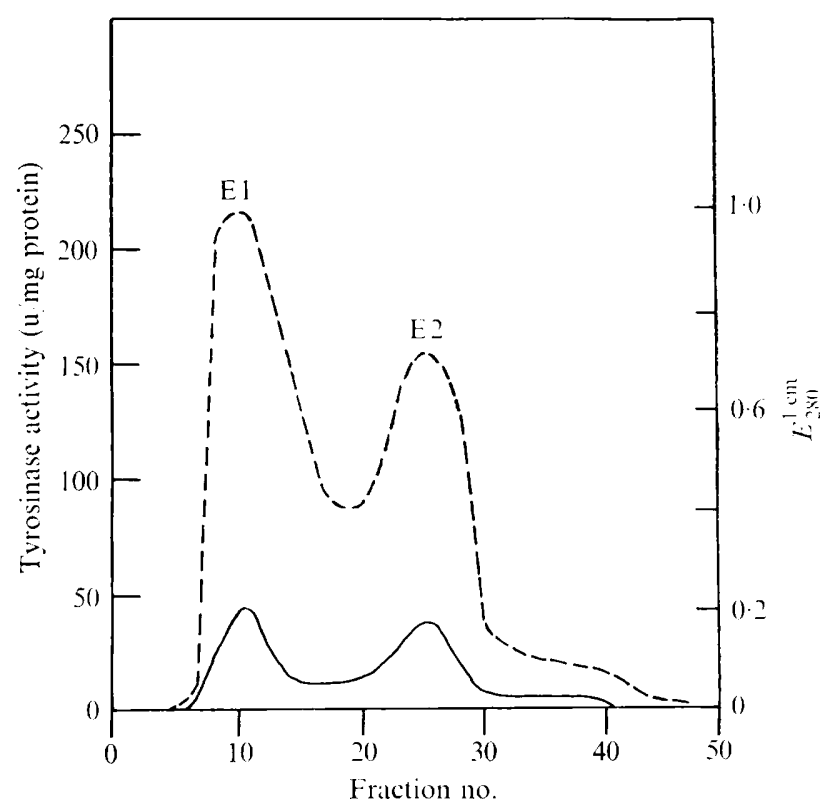

Fig. 2. Gel filtration of pooled tyrosinase fractions obtained by ion-exchange chromatography. Enzyme $(5 \mathrm{ml})$ was applied to a column $(35 \times \mathrm{I} \cdot 5 \mathrm{~cm})$ or Sephadex G-200, equilibrated with $5 \mathrm{~mm}-$ phosphate, $\mathrm{pH} 7 \cdot 0$, and containing $\mathrm{I} \mathrm{M}-\mathrm{NaCl}$. Elution was done with buffer of similar composition.

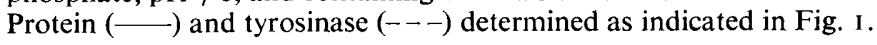

obtaining the phenol oxidase, and the use of anionic exchangers resulted in a considerable one-step purification of the enzyme. Fig. I illustrates the separation achieved on columns of DEAE-cellulose: the enzyme was absorbed very strongly at $\mathrm{pH} 8.2$ and was eluted only when the sodium chloride gradient approached $500 \mathrm{~mm}$. In this way approximately $\mathrm{r} 30 \mathrm{u}$ of phenol oxidase activity were recovered from $15 \mathrm{ml}$ of crude mycelial extract and the most active fractions oxidized $14.9 \mu \mathrm{mol}$ DOPA $/ \mathrm{mg}$ protein $/ \mathrm{min}$. Such experiments suggested that the enzyme was being separated from some inhibitory substance(s) during the elution and, in order to locate the inhibitor, samples of a standard enzyme preparation were incubated with all fractions collected from the DEAE-cellulose column before the elution of the enzyme, and the resulting activity measured. Inhibition was caused by a protein which was much less strongly adsorbed to the DEAE-cellulose than the phenol oxidase (Fig. I). Enzymeinhibitor separation also was possible on cationic celluloses but the degree of purification was only about a quarter of that obtained with the use of anionic materials.

When pooled enzyme fractions were recycled on G-200 Sephadex, two peaks of activity were resolved (Fig. 2). The specific activities of these two components were 2 I 5 (E I) and I 83 (E 2) $\mathrm{u} / \mathrm{mg}$ protein, i.e. a further $\mathrm{I}_{4}$ - and I 2 -fold purification.

Dialysis against 'Aquacide' (Calbiochem, Los Angeles, California, U.S.A.) and vacuum dialysis were tried as means of concentrating the purified enzyme but both proved unsuccessful, the result being a complete loss of activity. Neither the incorporation of cupric ions (I $\mathrm{mM}-\mathrm{CuSO}_{4}$ pentahydrate) into the dialysis medium nor the reconstitution of diffusate and non-diffusible fractions led to the restoration of activity. However, a twofold concentration was possible by incubating the enzyme solution with dry Sephadex G-25 in the cold for I 5 min. Approximately $80 \%$ of the enzyme was recovered from this treatment and its activity remained stable if it was stored frozen. 
Table I. Stoichiometry of DL-3,4-dihydroxyphenyl alanine oxidation by Aspergillus nidulans tyrosinase

The standard enzyme preparation used had an activity of approximately $0.5 \mathrm{u} / \mathrm{ml}$. For details of methods, see text.

$\begin{array}{cccc}\begin{array}{c}\text { Time } \\ (\mathrm{s})\end{array} & \begin{array}{c}\mathrm{I}, \mathrm{O}_{2} \text { consumed* } \\ (\mu \mathrm{mol})\end{array} & \begin{array}{c}\text { II, DOPA } \\ \text { oxidized } \dagger(\mu \mathrm{mol})\end{array} & \text { Ratio I : II } \\ 30 & 0.08 & 0.052 & \mathrm{I} \cdot 54 \\ 90 & 0.24 & 0 . \mathrm{I} 57 & \mathrm{I} \cdot 53 \\ \mathrm{I} 20 & 0.3 \mathrm{I} & 0.206 & \mathrm{I} \cdot 5 \mathrm{I} \\ & * \text { Polarographic measurements. } & \\ & + \text { Chronometric measurements. }\end{array}$

Table 2. Substrate specificity of Aspergillus nidulans tyrosinase

The activity is relative to the rate of DL-DOPA oxidation (100).

\begin{tabular}{lc}
\multicolumn{1}{c}{ Substrate (I mM) } & Relative activity \\
p-Cresol & 30 \\
L-Tyrosine & 26 \\
DL-3,4-Dihydroxyphenyl alanine & 100 \\
Catechol & 110 \\
4-Methylcatechol & 135 \\
p-Hydroquinone & 0 \\
Resorcinol & 0 \\
L-Ascorbic acid & 0
\end{tabular}

Enzyme kinetics. Numerous methods have been devised for the assay of phenol oxidases. An assay was needed which would allow initial reaction rates to be measured and would prevent the complication of secondary oxidations which would occur during prolonged incubation. The chronometric assay fulfilled both of these criteria: $o$-quinones did not accumulate and consequently secondary reactions could not proceed. The polarographic assay was extremely convenient to use and, because initial reaction rates could be determined very accurately, secondary reactions did not interfere with the measurements. Rates of reaction using these methods were strictly linear with increasing concentrations of enzyme. The stoichiometry of DL-DOPA oxidation was investigated by means of the chronometric and polarographic assays. Oxygen uptake:diphenol oxidized ratios calculated by this means are given in Table $\mathrm{I}$; molar ratios greater than $\mathrm{I}$ were observed.

The substrate specificity of the purified Aspergillus nidulans phenol oxidase is summarized in Table 2. These data are fully consistent with the description of this enzyme as a tyrosinase (EC. I.IO.3.I), namely the presence of ortho-hydroxylase and ortho-diphenol oxidase activities and the inability to oxidize meta- or para-diphenolic substrates. The action of the $A$. nidulans tyrosinase on DL-DOPA resembled closely that of tyrosinase of the common mushroom (Fig. 3) and the presence of broad extinction maxima at $305 \mathrm{~nm}$ and $475 \mathrm{~nm}$ indicated that indole-5,6-quinone 2-carboxylic acid (dopachrome) was an early product of the reaction (Bu'Lock, I960; see also Bull, 1970). The enzyme was also unable to oxidize $\mathrm{L}$-ascorbic acid, a result that justified the use of the chronometric assay procedure. The ratio of hydroxylase to oxidase activity in different batches of $A$. nidulans enzyme varied considerably and our best preparations had a ratio of 0.40 . All batches possessed the oxidase activity and the varying activity ratios reflected a greater or lesser loss of hydroxylase during the extraction and purification. Whilst the hydroxylase activity could be lost entirely, 


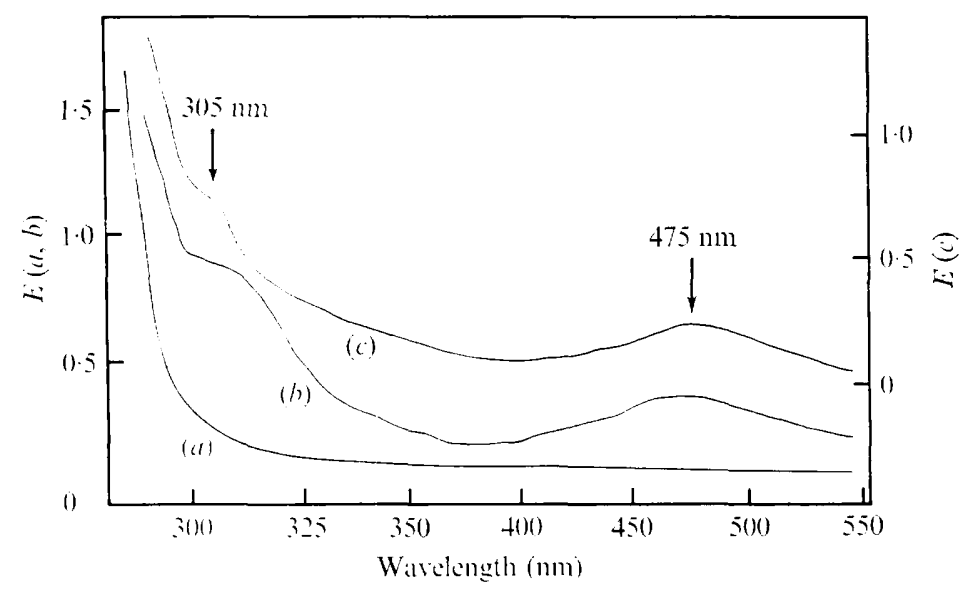

Fig. 3. Spectrophotometric analysis of the tyrosinase-DOPA reaction. (a) DL-DOPA substrate blank; (b) mushroom tyrosinase; (c) Aspergillus nidulans tyrosinase. Note offset scale for $(c)$.

preparations lacking $o$-diphenol oxidase were not obtained. Similarly the hydroxylase: oxidase ratio of tyrosinases prepared from a range of melanin mutants of $A$. nidulans (Bull \& Faulkner, 1965; Bull, 1970) ranged from infinity in the albino mutant I3. I .OL to 0.05 to 0.06 and 0.50 in dopachrome and melanochrome mutants respectively.

Typical Michaelis-Menten type kinetics were observed when the Aspergillus tyrosinase acted upon DL-DOPA and a $K_{m}$ of $250 \mu \mathrm{M}$ was calculated. Contrary to situations found with other phenol oxidases, inhibition by excess of substrate was not evident at high concentrations (cf. broad-bean tyrosinase activity reported by Robb, Swain \& Mapson, I966). The $K_{m}$ for oxygen, when DOPA (I mM) was the phenolic substrate, was found to be I $25 \mu \mathrm{M}$ (Fig. 4). The relatively low oxygen affinity of this enzyme compared with other oxidases emphasizes the need for vigorously aerated reaction mixtures when assaying phenol oxidases.

The latent tyrosinase present in the mycelia of Podospora anserina requires heat-activation before it can be detected (Esser, 1963). Heat-treatment of crude extracts of Aspergillus nidulans not only did not release tyrosinase activity but prevented its subsequent recovery via ion-exchange chromatography. However, the thermostability of the purified tyrosinase was considerable, the half-life at $60{ }^{\circ} \mathrm{C}$ being $32 \mathrm{~min}$. High thermostability is characteristic of several fungal tyrosinases including those of $P$. anserina (half-life at $60^{\circ} \mathrm{C}, 23 \mathrm{~min}$; Esser, 1963) and Neurospora crassa (half-life at $50^{\circ} \mathrm{C}, 95 \mathrm{~min}$; Fox \& Burnett, I962). The $A$. nidulans enzyme had a temperature optimum of approximately $40^{\circ} \mathrm{C}$ at $\mathrm{pH} 6.8$ and a broad $\mathrm{pH}$ optimum between 6.0 and 8.5 . Precise determinations of temperature and $\mathrm{pH}$ optima were difficult because of the extensive autoxidation of substrates under such conditions.

Aspergillus nidulans tyrosinase activity was inhibited by a number of chelating agents (Table 3), a result suggesting that the enzyme is a metal-containing oxidase. The tyrosine structural analogue, $\beta$-phenyl lactate, also was inhibitory. Inhibition by polyvinylpyrrolidone substantiated the inadvisability of using it to remove endogenous polyphenols from mycelial extracts. The endogenous protein inhibitor exerted a non-competitive effect on the native enzyme (Fig. 4).

Tyrosinase heterogeneity. It was shown above, by gel filtration, that the tyrosinase prepared by DEAE-cellulose chromatography comprised two components ( $E_{1}$ and $E_{2}$ ) which could be distinguished on the basis of their mol. wt (see Fig. 2). The close proportionality of protein 


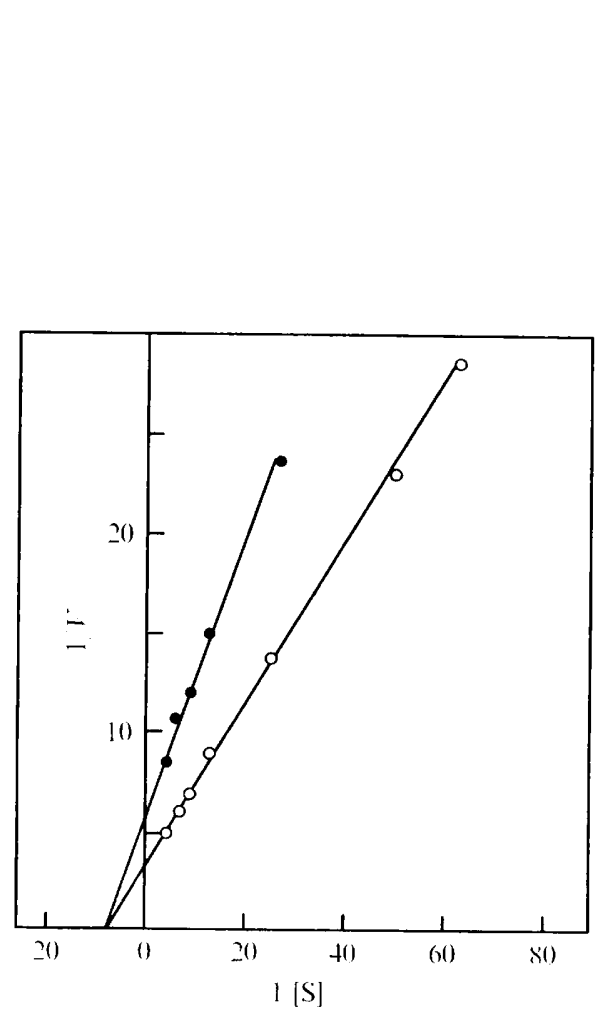

Fig. 4

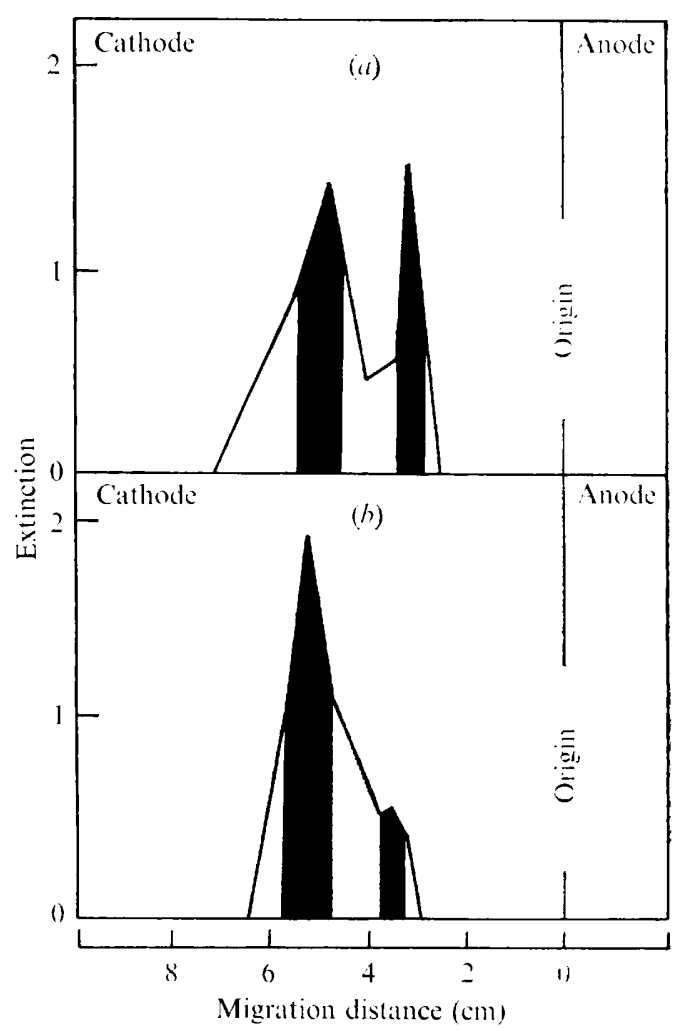

Fig. 5

Fig. 4. The effect of concentration (mM) of substrate $\left(\mathrm{O}_{2}\right)$ on tyrosinase activity and the kinetics of endogenous inhibitor action. Enzyme reaction rates were calculated from polarographic oxygenuptake recordings. DOPA ( $\mathrm{mm}$ ) was the phenolic substrate. $\bigcirc$, Tyrosinase alone; 0 , tyrosinase plus inhibitor.

Fig. 5. Paper electrophoresis of the high molecular weight tyrosinase, E 1. For operating conditions see Methods section. - - Protein trace; blocked areas define the tyrosinase activities.

Table 3. Effect of various inhibitors on Aspergillus nidulans tyrosinase activity

Substrate, DL-3,4-dihydroxyphenyl alanine (I mM).

Inhibitor

Sodium azide $(0 \cdot 1 \mathrm{~mm})$

Potassium cyanide (O. I mM)

Diethyldithiocarbamate (O. I mM)

Thiourea (I mM)

Cysteine (I mM)

$\beta$-Phenyl lactate ( $\mathrm{mm}$ )

Polyvinylpyrrolidone (1 \%)
Inhibition (\%)

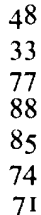

48

33

77

85

74

to tyrosinase activity during the elution from Sephadex G-200 was indicative of high enzyme purity, confirmed by subsequent electrophoretic analysis. The two tyrosinase components were recycled on calibrated columns of Sephadex G-200 and their molecular weights estimated as $5.2 \times 10^{5}\left(\mathrm{EI}_{1}\right)$ and $\mathrm{I} \cdot 3 \times 10^{5}\left(\mathrm{E}_{2}\right)$. The relationship between these two activities suggests a tetramer-monomer equilibrium but we never observed a tyrosinase activity corresponding to a presumed dimer state, i.e. an activity of a mol. wt $2.6 \times 10^{\overline{5}}$. The mol. wt 

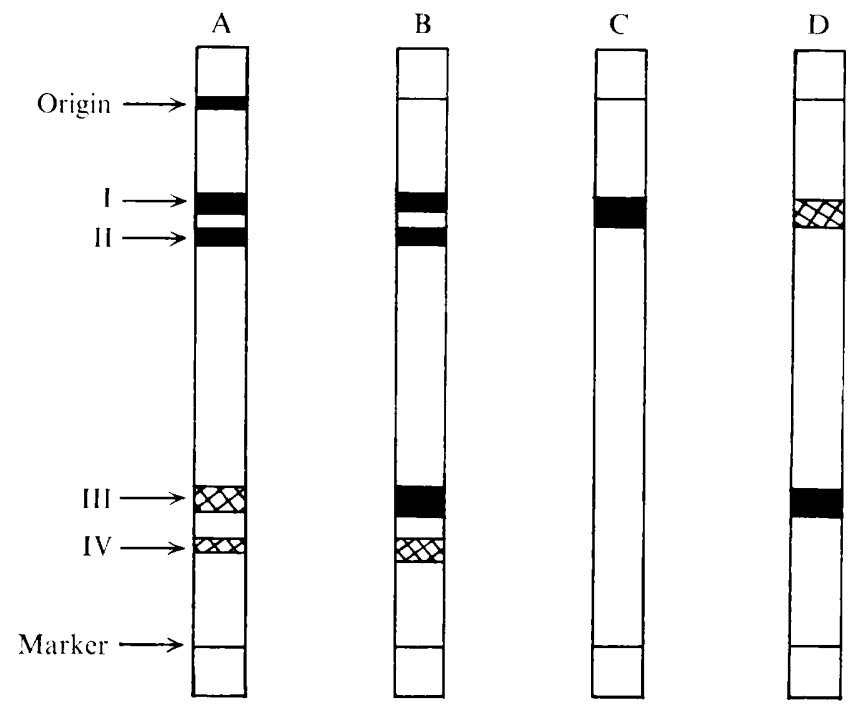

Fig. 6. Disc electrophoresis of tyrosinase components. For operating conditions see Methods section. A, Pooled enzyme from a DEAE-cellulose column; B, pooled enzyme from a DEAEcellulose column electrophoresed in the presence of Triton X-I00 ( $\mathrm{I} \%$ ); $\mathrm{C}$, high molecular weight enzyme EI ; and D, low molecular weight enzyme E2, isolated by Sephadex G-200 chromatography. Intensity of enzyme bands is indicated by the degree of hatching. Bromophenol blue was used as marker.

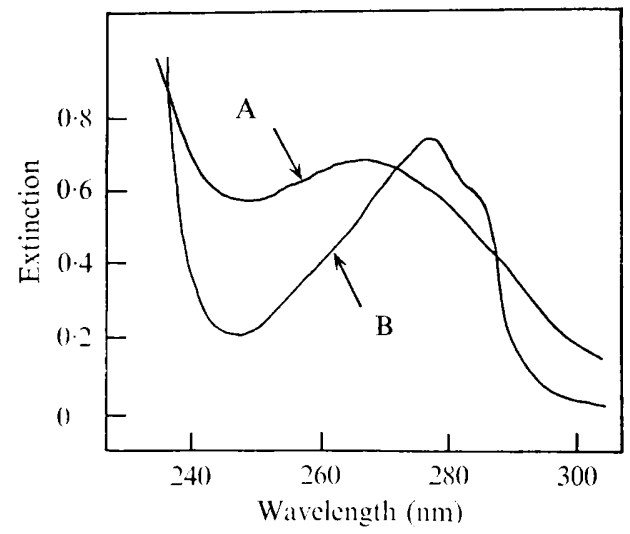

Fig. 7. Ultraviolet absorption spectra of Aspergillus nidulans tyrosinase (A) and endogenous inhibitor (B) isolated by DEAE-cellulose chromatography.

of the protein inhibitor was similarly estimated to be $\mathrm{I} \cdot 5 \times 10^{5}$. When the large mol. wt tyrosinase was analysed by low voltage paper electrophoresis two cathode-migrating components were detected (Fig. $5 a$ ). If the electrophoresis was done with paper pretreated with albumin, the two components observed initially again were detected (Fig. $5 b$ ) but the activity ratio of the faster to the slower moving component had changed from $2 \cdot 2$ to $6 \cdot 4$. The increased protein concentration after treatment of the paper probably prevented dissociation of the high mol. wt component (E I).

The heterogeneity of the Aspergillus nidulans tyrosinase was evident from polyacrylamide gel electrophoresis. Four bands (I, II, III, IV) of activity were detected when electrophoresis 
was done in the presence of Triton X-IOo; these four bands were present when Triton was omitted from the electrolyte but the intensity of the fastest moving activities, III and IV, was much reduced (Fig. 6). Electrophoresis of the high and low mol. wt tyrosinases prepared by gel filtration produced bands which corresponded to I+ II, and III, respectively. In the absence of Triton, tyrosine activity also was detectable at the origin, possibly representing an insoluble component.

Ribonucleoprotein nature of tyrosinase. The pooled tyrosinase activity eluted from DEAEcellulose had a slightly yellow colour and a single, rather broad absorbance maximum (Fig. 7). Absence of absorbance in the visible part of the spectrum indicated that the enzyme had not undergone autoxidation (tanning) during extraction. The high $E_{260} / E_{280}$ ratio $(\mathrm{I} \cdot 2)$ suggested that the enzyme might be ribonucleoprotein. Accordingly the purified tyrosinases (E I and E2) and the inhibitor (I) were analysed for RNA and protein with the following results: Protein ( $\mathrm{mg} / \mathrm{mg}$ enzyme), $0.63,0.60$ and 0.59 respectively; and RNA (mg/mg enzyme), $0.37,0.40$ and $0.4 \mathrm{I}$ respectively. Clearly both the purified enzymes and inhibitor contained large amounts of RNA in an almost constant ratio to protein.

\section{DISCUSSION}

The substrate specificity of the Aspergillus nidulans phenol oxidase indicated that it was a tyrosinase type (EC. I . IO.3. I) enzyme. This conclusion is substantiated by the pale yellow colour of the purified enzyme solution (cf. the blue colour of laccases), the extent of its molecular heterogeneity and its impressive heat-stability. The preparation procedure which has been developed produced tyrosinase with a high specific activity, pure on the basis of disc electrophoresis and without the disadvantage of enzyme tanning. The specific activity of our enzyme lay half-way between that of potato o-diphenol oxidase (Balasingam \& Ferdinand, 1970) and Neurospora crassa tyrosinase (Fling, Horowtiz \& Heinemann, 1963) but resembled the potato enzyme in oxidizing 4-methylcatechol at a greater rate than DOPA. The varying ratio of hydroxylating to oxidizing activities observed is typical of tyrosinases and this observation has been interpreted variously as (i) physico-chemical modification of a native enzyme during the course of its isolation and purification, or (ii) the coexistence of several native enzymes differing in their capacities to hydroxylate monophenols. We have not investigated the reason for variable activity ratios in the Aspergillus enzyme; the different ratios observed in several batches of wild-type enzyme and characteristic of mutant strains could be attributable to either of these alternatives. The $K_{m}$ for DL-DOPA of $A$. nidulans tyrosinase is very similar to that of Neurospora (Horowitz \& Shen, 1952), mushroom (Yanosuba, 1959) and mammalian (Pomerantz \& Warner, 1967) phenol oxidases. In contrast, angiosperm tyrosinases have a much lower affinity for DOPA (Alexander, I966; Robb, Swain \& Mapson, I966). The $A$. nidulans tyrosinase had a rather low affinity for its nonphenolic substrate, oxygen. The low $K_{m}\left(\mathrm{O}_{2}\right)$ may be relevant in attempting to ascribe a role for the enzyme in vivo (see below). The ratio of $\mathrm{I} \cdot 5$ for oxygen consumed to DOPA oxidized is at variance with that usually proposed for $o$-diphenol oxidation, i.e. 0.5 . Secondary oxygen-consuming reactions occurring during the polarographic assay may account for an overestimate of the oxygen uptake. However, this situation is improbable in view of the constancy of the oxygen-uptake rate over an incubation time of I20 s. Likewise oxygen limitation under the conditions of the chronometric assay is a dubious explanation because an increase in the enzyme concentration produced a linear increase in the reaction rate. At present we cannot explain these data. Other workers, notably Mayer et al. (I966), also have observed a non-theoretical stoichiometric relationship for $o$-diphenol oxidation. As a conse- 
quence, exact measurements of tyrosinase activity are difficult and we agree with Mayer et al. (I966) that, because of the ease of accurately determining initial rates, the polarographic method should be the assay of choice.

The non-competitive inhibition of the Aspergillus nidulans tyrosinase by an endogenous protein indicates that the latter was not simply a second enzyme system competing for the substrate oxygen. It is conceivable that an irreversible tyrosinase-inhibitor complex was formed which produced a situation similar to the inhibition of mushroom tyrosinase by its apoenzyme (Karkhanis \& Frieden, I96I). However, whereas the mushroom tyrosinase inhibitor can be converted to a fully active enzyme by the addition of cupric ions, the $A$. nidulans inhibitor did not respond to such treatment. Horowitz \& Shen (I952) observed an endogenous inhibition of tyrosinase in Neurospora crassa which could be relieved by dialysis. Again the $A$. nidulans enzyme responded differently, dialysis resulting in the total loss of enzymatic activity. The endogenous inhibitor may have a role in vivo or merely be a preparative artifact. It may be significant that growth conditions (sulphur limitation, Horowitz \& Shen, 1952 ; surface cultivation, Hirsch, 1954) influence the formation of $N$. crassa tyrosinase inhibitor. Moreover, evidence is accumulating for the widespread occurrence of endogenous protein inhibitors of phenol oxidase in fungi (Madhosingh, 1970).

The Aspergillus nidulans tyrosinase appears to have the highest mol. wt of any phenol oxidase isolated so far from fungi although enzymes of comparable size have been reported in the blow fly (Karlson \& Liebau, I96I) and tea leaf (Takeo \& Uritani, 1966). The evidence from gel filtration and disc electrophoresis strongly suggests that the Aspergillus tyrosinase is a tetrameric enzyme and that its heterogeneity is due partly to association phenomena. The increased number of components revealed by disc electrophoresis, especially in the presence of surfactants, probably represents microheterogeneity at the tertiary protein structure level. Exhaustive kinetic analyses of the tyrosinase isoenzymes has not been made but they appear to be indistinguishable on the basis of their substrate specificities. Martinelli \& Bainbridge (1969) have described five $o$-diphenol oxidase components in wild-type $A$. nidulans, one of which was thermolabile.

The behaviour of the Aspergillus nidulans tyrosinase on DEAE-cellulose is consistent with it being a highly acidic polymer. This feature of the enzyme can be exploited for producing a high specific activity by a single step procedure. Although the ultraviolet absorption spectrum of the tyrosinase suggested considerable nucleic acid contamination $\left(E_{\max }\right.$ at $265 \mathrm{~nm}$, $E_{260} / E_{280}$ of $\mathrm{I} \cdot 2$ ), the nucleic acid (identified as RNA) remained associated with the mono- and tetrameric activities following their subsequent purification. While this work was in progress, Balasingam \& Ferdinand (1970) published results of their analysis of potato $o$-diphenol oxidase and concluded that this enzyme was a ribonucleoprotein. The potato enzyme has many properties in common with that from $A$. nidulans $\left(E_{\max }\right.$ at $263 \mathrm{~nm}, E_{260} / E_{280}$ of I.I; equal amount of RNA and protein by weight) and both are clearly distinguishable by these criteria from $o$-diphenol oxidases of other fungi (Bouchilloux, McMahill \& Mason, 1963; Fling et al. 1963) and of broad bean (Robb et al. 1965). The exact relationship between the protein and the RNA in these enzymes remains to be elucidated. A straightforward contamination of the enzyme with RNA during extraction cannot be ruled out but Balasingam \& Ferdinand (1970) were unable to remove the RNA without destroying the activity nor was it susceptible to pancreatic ribonuclease. The absorption spectrum of the endogenous inhibitor (Fig. 7) resembled much more closely that of a protein rather than a ribonucleoprotein; nevertheless, chemical analysis revealed an RNA content similar to that of the enzyme. At present we cannot explain these results.

A role for phenol oxidases in the metabolism of fungi has been sought by several investi- 
gators but convincing experimental support for the various proposals has been lacking. In an earlier publication (Carter \& Bull, 1969) we described the effect of specific growth rate on tyrosinase synthesis in Aspergillus nidulans. These observations, together with the data presented in this paper, prompt us to suggest a physiological role for tyrosinase in this fungus. When $A$. nidulans is growing at a maximum rate in batch cultures or at a high dilution rate in carbon-limited chemostats, a shift in metabolism to aerobic fermentation occurs accompanied by a corresponding decrease in mitochondrial respiration (Carter \& Bull, I969; Carter et al. 197I ). Significantly the specific activity of tyrosinase increases several-fold under these circumstances, a result which strongly favours a role for the enzyme in primary metabolism. For the present it seems plausible to view tyrosinase as having a function analogous to peroxisomal oxidases and catalase in animal and plant cells (Baudhuin, I969), namely in reoxidizing extramitochondrial reduced dinucleotide coenzymes. Three lines of evidence are consistent with this hypothesis: (i) the tyrosinase of $A$. nidulans occurs both in the particulate and soluble cell fractions (B. L. A. Carter, unpublished data; Martinelli \& Bainbridge, 1969); (ii) the tyrosinase has a low affinity for oxygen and its activation in vivo is likely whenever the cellular oxygen level increases, e.g. when mitochondrial respiration is repressed at high dilution rates; (iii) the oxygen uptake rate of whole mycelia is markedly depressed by the tyrosine analogue DL- $\beta$-phenyl lactic acid (see also the effect on tyrosinase activity in vitro; Table 3 ). Results similar to these were considered by Demopoulos \& Kaley (1963) to indicate a tyrosinase-mediated respiratory component in mouse melanomas.

More difficult to define is the function of the endogenous tyrosinase inhibitor in this and in other fungi. Teleologically, it would seem disadvantageous for the fungus to divert carbon skeletons into melanin synthesis during rapid growth. The inhibitor could act as a safety mechanism, trapping any tyrosinase which enters the cytoplasm and thereby preventing indiscriminate melanin formation in the cytoplasm. Melanin synthesis does not proceed under conditions of high growth rate or high dilution rate (Carter \& Bull, I969). Certainly many aspects of this hypothesis require rigorous testing; we have no clue, for example, as to the nature of the system, whose existence it is necessary to invoke, which would link the DOPA-DOPAquinone and dinucleotide-reduced dinucleotide couples. However, we hope that this interim model will be sufficiently thought provoking to stimulate further research in this area of fungal physiology.

We thank the Science Research Council and the Central Research Fund of London University for financial support.

\section{REFERENCES}

AleXANDer, A. G. ( 1966 ). The oxidizing enzymes of sugar cane, tyrosinase. Journal of Agriculture, University of Puerto Rico 50, I I 3-I 29.

Balasingam, K. \& Ferdinand, W. (1970). The purification and properties of a ribonucleo-enzyme, $o$ diphenol oxidase, from potatoes. Biochemical Journal $\mathbf{1 1 8}, 15-23$.

Baudhuin, P. (1969). Peroxisomes (microbodies, glyoxysomes). In Handbook of Molecular Cytology, pp. I 179-1 195. Edited by A. Lima-de-Faria. Amsterdam and London: North-Holland Publishing Co.

Bouchilloux, P., McMahill, P. \& Mason, H. S. (I963). The multiple forms of mushroom tyrosinase. Purification and molecular properties of enzymes. Journal of Biological Chemistry 238, I 699-1707.

Bull, A. T. (1970). Chemical composition of wild-type and mutant Aspergillus nidulans cell walls. The nature of polysaccharide and melanin constituents. Journal of General Microbiology 63, 75-94.

Bull, A. T. \& Faulkner, B. M. (1964). Physiological and genetic effects of 8-azaguanine on Aspergillus nidulans. Nature, London $\mathbf{2 0 3}, 506$.

Bull, A. T. \& Faulkner, B. M. (1965). Melanin synthesis in wild-type and mutant strains of Aspergillus nidulans. Journal of General Microbiology 4r, iv. 
Bu'Lock, J. D. (1960). Intermediates in melanin formation. Archives of Biochemistry and Biophysics 9I, I 89-I 93.

Carter, B. L. A. \& Bull, A. T. (I969). Studies of fungal growth and intermediary carbon metabolism under steady and non-steady state conditions. Biotechnology and Bioengineering II, 785-804.

CARTER, B. L. A. \& Bull, A. T. (197I). The effect of oxygen tension in the medium on the morphology and growth kinetics of Aspergillus nidulans. Journal of General Microbiology 65, 265-273.

Carter, B. L. A., Bull, A. T., Pirt, S. J. \& Rowley, B. I. (I971). Relationship between energy substrate utilization and specific growth rate in Aspergillus nidulans. Journal of Bacteriology 108, 309-3I 3.

Davies, B. J. (1964). Disc electrophoresis. II. Methods and applications to human serum proteins. Annals of the New York Academy of Sciences I2I, 404-427.

Demopoulos, H. B. \& Kaley, G. (I963). Selective inhibition of respiration of pigmented S-9I mouse melanomas by phenyl lactate and possibly related effects on growth. Journal of the National Cancer Institute 30, 6I I-63I.

El-Bayoumi, M. A. \& Frieden, E. (1957). A spectrophotometric method for the determination of the catecholase activity of tyrosinase and some of its applications. Journal of the American Chemical Society 79, 4854-4858.

Esser, K. (1963). Die Phenoloxidasen des Ascomyceten Podospora anserina. I. Die Identifizierung von Laccase und Tyrosinase beim Wildstamm. Archiv für Mikrobiologie 46, 2 I 7-226.

Fling, M., Horowitz, N. H. \& Heinemann, S. (1963). The isolation and properties of crystalline tyrosinase from Neurospora. Journal of Biological Chemistry 238, 2045-2053.

Fox, A. S. \& BurnetT, J. B. (1962). Tyrosinases of diverse thermostabilities and their interconversion in Neurospora crassa. Biochimica et biophysica acta 6r, $108-120$.

HirsCH, H. M. (1954). Environmental factors influencing the differentiation of protoperithecia and their relation to tyrosinase and melanin formation in Neurospora crassa. Physiologia plantarum 7, 72-97.

Horowitz, N. H. \& Shen, S. C. (1952). Neurospora tyrosinase. Journal of Biological Chemistry 197, 51 3-520.

Karkhanis, Y. \& Frieden, E. (196I). Tyrosinase inhibition by its apoenzyme and the transformation of a protein inhibitor into tyrosinase. Biochemical and Biophysical Research Communications 4, 303-308.

Karlson, P. \& Liebau, H. (I96I ). Zum Tyrosinstoffwechsel der Insekten. V. Reindarstellung, Kristallisation und Substratspezifität der 0 -Diphenoloxydase aus Calliphora erythrocephala. Hoppe-Seyler's Zeitschrift für physiologische Chemie 326, I 35-I43.

Karlson, P., Mergenhager, D. \& Sekeris, C. E. (I964). Zum tyrosinstoffwechsel der insekten. XV. $o$-Diphenoloxydase aus Calliphora erythrocephala. Hoppe-Seyler's Zeitschrift fiir physiologische Chemie $33^{8}, 42-50$.

Lowry, O. H., Rosebrough, N. J., Farr, A. L. \& Randall, R. J. (I95I). Protein measurement with the Folin phenol reagent. Journal of Biological Chemistry I93, 265-275.

Madhosingh, C. (1970). Tyrosinase isoenzymes in six agaric species of Basidiomycetes. Canadian Journal of Microbiology 16, 895-899.

Martinelli, S. D. \& Bainbridge, B. W. (1969). Phenol oxidases produced by mutant and wild-type strains of Aspergillus nidulans. Biochemical Journal I14, I 0 .

Mayer, A. M., Harel, E. \& Ben-Shaul, R. (1966). Assay of catechol oxidase - a critical comparison of methods. Phytochemistry 5, 783-789.

PomerantZ, H. (1963). Separation, purification and properties of two tyrosinases from hamster melanoma. Journal of Biological Chemistry 238, 2351-2357.

Pomerantz, H. \& WARner, M. V. (1967). 3,4-DOPA as the tyrosinase co-factor. Occurrence in melanoma and binding constant. Journal of Biological Chemistry 242, 5308-53 I4.

Robb, D. A., Mapson, L. W. \& SwaIn, T. (1965). On the heterogeneity of the tyrosinase of broad bean (Vicia faba L.). Phytochemistry 4, 73 I-740.

Robb, D. A., Swain, T. \& Mapson, L. W. (1966). Substrate and inhibitors of the activated tyrosinase of broad bean. Phytochemistry 5, 665-675.

SANDERSON, G. (I965). The action of polyphenolic compounds on enzymes. Biochemical Journal 95, $24 \mathrm{P}$.

SCHNeIder, W. C. (1957). Determination of nucleic acids in tissues by pentose analysis. In Methods in Enzymology, vol. III, pp. 680-684. Edited by S. P. Colowick and N. O. Kaplan. New York: Academic Press.

Takeo, T. \& Uritani, I. ( I 966). Tea leaf polyphenol oxidase. II. Purification and properties of the solubilized polyphenol oxidase in tea leaves. Agricultural and Biological Chemistry 30, I 55-1 63.

Yasunobu, K. T. (1959). Mode of action of tyrosinase. In Pigment Cell Biology, pp. 583-608. Edited by M. Gordon. New York: Academic Press. 